\title{
2. 成果主義の功罪一労務管理 (成果主義)とストレスを中心に一
}

\author{
横山敬子 \\ プール学院大学短期大学部
}

1.はじめに

日本において成果主義が導入され、話題となったのは 1992 年のことで富士通が最初のケースであった。 90 年代から最近まで続いた不況とともに、人件費の削減を実現するための手段として、成果主義を取 り入れる企業が増加してきている。たとえば 2004 年労働政策研究・研修機構「労働者の働く意欲と雇 用管理のあり方に関する調查」の 10000 社調查によれば、63.5\%の企業が成果主義を導入している。

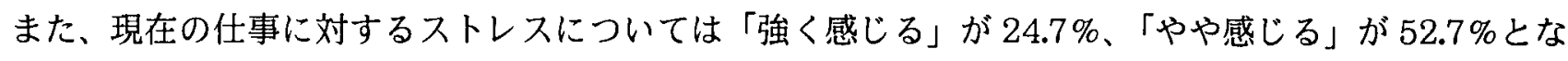
っており、77.4\%の労働者がストレスを感じている。成果主義からストレスを引き起こしたという実証 研究は私の力量では発見できなかったが、この因果関係の仮説を構築することは可能であると考えられ る。このような状況が続けばストレスから精神的、肉体的な病気を引き起こすかもしれない。これらが 現実とならないような人事労務管理、広くはマネジメントの変革を考えたい。

\section{2. バーンアウト調査}

ストレスから引き起こされる症状のひとつにバーンアウトがある。バーンアウトは DSM-4、ICD-10

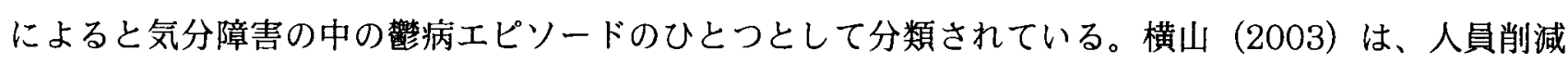
（リストラ）の後、従業員にみられるバーンアウト現象を取り上げ、いかなる職務要因でバーンアウト するのか、その結果どのような事態が起こるのかを明らかにするために調査を行った。調査は希望退職 から退職勧奖まで何らかの雇用調整を経験している 14 社、587 人に対し 1999 年に行われた。その結 果、役割曖昧、役割過重があり、上司のサポートが欠如した場合にバーンアウトを引き起こしやすくな ることが判明した。

\section{3. 面接調査}

共分散構造分析を用いたために因果関係の方向は分かっても、調查票による調查ではなぜそのよう になるのかという部分までは解明されない。よって面接を行うことによりこの部分を明らかにしようと した。面接は 14 社のうち承諾が得られた 8 社の取締役・部長 8 名に対して半構造化面接法を用い、情 報による分類としては深層面接法を採用して行われた。

その結果、8 社のうち 7 社が成果主義を採用していることが分かった。

その中で成果主義の持つ問題点が指摘された。(1)低い予算のところ、伸びない商品を扱っていては頑張 っても販売には限界があり、なかなか成果が出せない。結果にいたる難易度も見てほしい。(2)チームワ 一クの仕事の評価が難しい。(3)透明性、客観性がある目標を立てるのが難しい。(4)必ず会社には 2 割く らいのだめな社員がいる。その人達を切っても、また、残りの人達のうち 2 割がだめな社員となる。成 果主義は総力としての会社のレベルアップに慗がるのか疑問だ。(5)成果主義の細かいやり方はその会社 のニーズ、企業文化により違ってくるだろう。 
4. 成果主義は本当に問題なのか

2004 年度の労働政策研究・研修機構の調査から、労㗢者の仕事全体についての満足度と企業の雇用 方針との関係を見ると、「従業員の能力・適性によって早い段階から配置・育成について差別化を図る」 という方針が「当てはまる」企業では、「当てはまらない」とする企業に比べて、仕事に満足している 労働者の割合が高い $(45.4 \%: 40.1 \%)$ 。また、雇用管理制度との関係を見ると、「目標管理制度」を導 入している企業と導入していない企業では、満足度は導入している企業のほうが高い $(43.1 \%: 40.8 \%)$ 。 さらに、「仕事の成果を賃金に反映させる制度」を導入している企業の方が、導入していない企業より 満足度が高い $(44.1 \%: 39.7 \%)$ 。成果主義を採用している会社のほとんどがこれらの3 項目を使用し ていると思われる。よって、この調查が示す限りでは、成果主義も思われているほど問題を含んでいな いのかもしれない。

また、同様の調查によると、今後 3 年間で成果主義を採用する企業は 1 万社のうち $88.1 \% に も$ 登り、 もはや成果主義の流れをとどめることは難しい。

5.よりよい成果主義にするために

面接調查で明らかになった成果主義の問題点をまとめると、(1)から（3)関してはプロセス評価を加え ていないために起こった問題であると考えられる。つまり、実績を出すに至った方法や環境（たとえば 売れない地域の店）を考慮し、企業倫理や社会性も考慮する（環境に優しいことを企業理念とする会社 で、課長が産業廃棄物の不法投棄を行っては利益を上げたとしても低い評価にすべきである）必要があ る。(4)に関しては配置を行う人事部の力量次第で变わる可能性がある。管理職の評価は部下の成果によ り大きく左右される。成果主義になると管理職は優秀でない部下を持ちたがらなくなるだろう。優秀で ない中間管理職に成果を出させるためには優秀な部下を下につける必要がある。したがって会社総体と

して好業績を出させるには人事部の采配が重要である。

また、再現性を可能にするためにコンピテンシー評価を含めることも必要と思われる。以上に加え、 役割過重、役割曖昧、上司のサポートに気をつけることも重要であろう。役割過重とは単に仕事量が多 いだけでなく、周囲からの過剰な期待、高い遂行基準、権限がないのに責任ばかり押し付けられるとい うことが含まれ、よって疲れきってバーンアウト状態になる。また、役割曖昧が強く仕事の目標と目的 が分からず、自分の権限と責任範囲がはっきりしなければやはりバーンアウト状態になるだろう。上司 のサポートがない場合、つまり上司が部下を信頼し、理解し、双方のコミュニケーションが取れている ということがなければ、やはりバーンアウトするであろう。しかし上記と同様の仕事であっても上司の サポートがある場合はバーンアウトしないかもしれない。これらを押さえることで成果主義の問題点を かなりの程度まで克服することができると考える。

\section{（参考文献）}

有賀誠 (2002)「評価システム」『MBA 人材マネシメント』タイイアモンド社

守島基博（2004）「成果主義に関する論点整理」『企業の経営戦略と人事制度などに関する研究の論点整理』労働政策 研究報告書 No.7 労働政策研究・機構

横山敬子（2003）『仕事人間のバーンアウト』白桃書房

『労働者の働く意欲と雇用管理のあり方に関する調查』(2004)JILPT 調查シリースNo.1 労働政策研究・研修機構 